\title{
Chapter 9 \\ Between Reception, Legal Stay and Integration in a Changing Migration Landscape in Greece
}

\author{
Christos Bagavos, Nikos Kourachanis, Konstantina Lagoudakou, \\ and Katerina Xatzigiannakou
}

\subsection{Introduction}

Greece, historically considered a typical emigration country, experienced two significant periods of outward migration: the first took place in the early twentieth century (1900-1920), while the second extended from the end of World War II to the first half of the 1970s (Bagavos 2015; Hassiotis 1993; Lazaretou 2016). The United States was by far the main destination country over the first period, whereas in the second period the largest majority of emigrants moved to the Federal Republic of Germany. Between 1900 and 1920, around 400,000 people emigrated abroad; during 1955-1975 the figure was almost 1.2 million (Bagavos 2015). From 2009 onward, a third emigration period occurred as a result of the economic downturn (Labrianidis and Pratsinakis 2016). Estimates for the entire 2009-2017 period indicate that emigration, including both national and foreign populations, accounts for around 850,000 persons (EL.STAT. 2019a).

As for immigration, the 1990s mark a turning point in the history of Greek migration since the country had by this period received a significant number of immigrants. Although the second half of the 1970s and the whole of the 1980s can be considered as the starting period of migration inflows to Greece, the last decade of the twentieth century is marked by unprecedented immigration waves of foreigners coming mainly from the Balkans and to a lesser extent from Asian countries (Cavounidis 2015). Moreover, from 2014 onward, subsequent to the refugee crisis, a substantial number of arrivals, estimated at around 1.2 million third-country nationals and almost 850,000 in the year 2015 alone (UNHCR 2019), was recorded. Consequently, the foreign population increased from 167,000 to more than 800,000 between 1991 and 2018 (Bagavos 2015; EL.STAT. 2019b) and the share of

C. Bagavos $(\bowtie) \cdot$ N. Kourachanis $\cdot$ K. Lagoudakou $\cdot$ K. Xatzigiannakou Department of Social Policy, Panteion University of Social and Political Sciences, Athens, Greece 
foreigners to the total population went from $1.6 \%$ to $7.6 \%$ (from $1 \%$ to $5.6 \%$ for third-country nationals). Inevitably, immigration, either in terms of transit or of settled immigrants, has become a major policy issue and has mobilized the national authorities, international bodies as well as formal and informal civil society organizations. In addition, the shifting immigration landscape in Greece has led to the changing composition of migrants and of migrants' needs; immigrants from the period before 2014, who are quite well integrated in Greek society, coexist with refugees and asylum seekers for whom reception conditions have been the main concern.

Changes in the immigration landscape were coupled with adverse economic conditions from 2009 onwards. Unemployment rose sharply and GDP fell significantly. Unemployment rates increased from $7.8 \%$ in 2008 to $24.9 \%$ in 2015 and reached $23.6 \%$ in 2016. Long-term unemployment rates as a percentage of total unemployment rose from $47.0 \%$ in 2008 to $73.4 \%$ in 2014 , reaching $71.8 \%$ in 2016 . In addition, GDP decreased by around $28 \%$ between 2008 and 2016. In this context along with austerity measures the labor market has undergone a number of major changes, among them the stifling control over the shaping of the labor law. Thus, despite the end of the economic tutelage of Greece by the International Monetary Fund (IMF) and the EU in August 2018, the situation in the Greek labor market, after several years of austerity, is still one of deregulation. This gloomy economic and labor market environment did not favor the integration of MRAs into the labor market. With widespread unemployment, the prospect of developing targeted employment policies for MRAs seems impractical, since employment policies are mainly oriented towards the fight against overall unemployment. At the same time, economic hardship has particularly affected those sectors where MRAs are mainly employed, such as construction, retail and personal and domestic services.

The chapter deals with the main legislative developments in migration and the integration of MRAs into the labor market over recent years. It seeks to highlight the significant differences between migrants and refugees in terms of the legal framework put in place by the public authorities to effectively manage the migration phenomenon and the integration of MRAs into the labor market. The chapter stresses that changes in the immigration landscape, along with adverse economic conditions, have led to further efforts by the public authorities for the effective management of refugee flows and reducing the risks of irregular stay for a significant number of migrants. These efforts, however, underestimate the importance of issues relating to the integration of MRAs into the labor market. The paper is structured as follows: Section 9.2 presents the legislative framework on migration and asylum, while Sect. 9.3 deals with legislation on the integration of migrants, asylum seekers and refugees into the Greek labor market. The main concluding remarks are included in Sect. 9.4. ${ }^{1}$

\footnotetext{
${ }^{1}$ As this chapter was being finalised a new law was adopted (the International Protection Act $\mathrm{L}$ 4636/2019) which establishes a 6-month employment ban for asylum seekers to occur from 1.1.2020.
} 


\subsection{The Legislative Framework in the Fields of Migration and Asylum}

\subsubsection{Developments in the Legislative Framework of Migration}

The Immigration and Social Integration Code (Law 4251/2014) voted in by Parliament in April 2014 is the most significant development in managing migration over the recent period. The modifications introduced aim to simplify procedures, revise terms for access to the labor market, encourage investment by third-country nationals, modify terms and conditions for granting long-term residence permits, and to ensure the legal stay of the second generation of third-country migrants.

One of the most relevant aspects of the Code is that it seeks to simplify and better manage the procedures for residence permits, with the aim of reducing the risks of irregularity for a significant number of migrants, in particular within the context of the persistent economic recession (Greek Parliament 2014; Kapsalis 2018a; The Greek Ombudsman 2013). The promotion of the legal stay of migrants is reflected in various provisions, such as the increase in the length of the validity of the initial permits and the renewed residence permits, from 1 to 2 years and from 2 to 3 years respectively, and the issuing of a document, in practice a temporary permit to stay which is valid for 12 months and that certifies that a third-country national has submitted a complete application for the issuing or renewal of a permit to stay (Triandafyllidou 2015).

The Code also promotes the status of long-term residence for third-country nationals who have lived in Greece for a long period, enabling the holder to move to and work in all EU countries, a right not granted to holders of the 10-year residence permit. In addition, a second-generation residence status has been adopted (Article 108), which grants a 5-year residence permit that can be renewed simply by presenting the previous residence permit to adult third-country nationals born in Greece or those who have successfully completed six Greek school grades in Greece before their 21st birthday, and who are legally resident in Greece.

The Code's provisions, further strengthened by Law 4332/2015, also offer a 2 -year residence permit and access to the labor market to third-country nationals on the basis of exceptional grounds (The Greek Ombudsman 2015). This permit is granted if the interested third-country national has procured a visa issued by a Greek consular authority at least 3 years before submission of the application, or a permanent residence permit even if it had expired in the previous 10 years, or that he or she can prove by way of dated documents the actual fact of his or her residence in the country for at least seven instead of 10 consecutive years, as foreseen by the Code. In the above cases, the third-country national must prove that he or she has long-lasting ties ${ }^{2}$ with the country unless he or she had a residence permit for Greece for at least 5 years in the decade prior to the application (Spirou 2017).

\footnotetext{
${ }^{2}$ Factors considered as proof of strong ties with the country are: very good Greek-language skills; attendance of a Greek primary or secondary school by the applicant or his or her children; duration
} 
Another important aspect is that the Migration Code and Law 4332/2015 regulate the entry and residence of seasonal ${ }^{3}$ migrants in order to work in agriculture and the fisheries industry (EMN 2015; Triandafyllidou 2015). On the basis of a simplified entry procedure, permits are provided to third-country nationals for seasonal residence and work and several guarantees are foreseen as regards social rights (for more details see Sect. 9.3.2).

Further provisions were introduced by Joint Ministerial Decision 30651/2014 and Law 4332/2015, which regulate the reasons and procedures for granting a 2-year residence permit on humanitarian grounds to several categories of thirdcountry nationals, such as victims of trafficking, crime and domestic violence, or those who work in inappropriate working conditions, or suffer from serious health problems or follow an approved mental health treatment programme. Those provisions are also applied to victims of violations of Article 3 of the European Convention for the Prevention of Torture and Inhuman or Degrading Treatment or Punishment, Article 3 of the Convention for the Protection of Human Rights and Fundamental Freedoms or Article 3 of the New York Convention against Torture and Other Cruel, Inhuman or Degrading Treatment etc., that is to people who have suffered "inhuman or degrading treatments or punishments" (Council of Europe 1950).

This legislative framework, implemented in the context of a long-standing economic recession, led to a simplification of the procedure and extending the legal residence of third-county nationals (Triandafyllidou and Gemi 2018). In this respect, there is no doubt that the legislation has contributed to regularizing the stay of a significant number of irregular migrants even on humanitarian or exceptional grounds. Nevertheless, developments in the legal and institutional aspects of migration issues mainly reflect the efforts to manage existing migration rather than to provide a perspective for facilitating and sustaining future legal labor migration.

\subsubsection{Migrants, Refugees and the EU-Turkey Statement}

The EU-Turkey Statement provides the main framework for the management of refugee flows over the last 4 years in Greece. The 2015 refugee crisis in Europe led to the involvement of the European Union through the identification of measures aiming to better manage refugee flows. At the beginning of 2016, the Member States recognized the need for further measures to manage issues emanating from the refugee crisis, which led to the EU-Turkey Statement.

Of course, the issues covered by the EU-Turkey Statement and its importance in controlling the number of arrivals, the protection of a migrant's fundamental rights and compliance with international standards have been widely discussed over the

of residence, primarily legally, in Greece; social security contributions; fulfilment of tax obligations; and blood relations with a Greek national or expatriate.

${ }^{3}$ Seasonal work refers to activity performed in Greece for up to 3 months in total within a 12-month period, in a field related to provisional and seasonal employment. 
recent period. The basic content of the Statement is that all people irregularly arriving in the Greek islands will be transferred back to Turkey. For each Syrian returning to Turkey from the Greek islands, another Syrian will be relocated from Turkey to the EU (the 'One for One' procedure). In addition, the agreement includes a commitment for the EU to cooperate with Turkey in order to facilitate the provision of reception services to refugees returned to Turkey, and to establish so-called 'safe areas' inside Syria.

The statement has been criticized as being legally problematic, impractical to implement, and in contravention of refugee law (Amnesty International 2017; Kourachanis 2018). The statement, without being a convention of the Union with a third country, from a legal aspect introduces a host of derogations from the EU regulatory framework (The Greek Ombudsman 2017). It is also seen as unclear on how individual needs for international protection would be fairly assessed during the mass expulsions (Amnesty International 2017). Indeed, Turkey has ratified the 1951 Refugee Convention, but only by applying a geographical limitation whereby only Europeans can be granted refugee status in the country, making the EU's recognition of Turkey as a safe third country rather problematic (Spyropoulou and Christopoulos 2016). At the same time, the scope for establishing 'safe areas', in the current situation, seems to be unrealistic.

Although the EU-Turkey Statement is not related in a direct way to issues of asylum seekers' integration into the labor market, many scholars comment that it provides a preparatory stage for their deployment in low-status sectors (Kourachanis 2018; Xypolytas 2017). The unfavorable living conditions of asylum seekers in hotspots and camps risks making them willing to take up any job and any employment relationship and hence being more vulnerable to exploitation.

\subsubsection{Developments in the Legislative Framework of Asylum}

Changes in the legislation on asylum over the recent period were undertaken in the context of the refugee crisis and Greece's international legislative commitments. These changes mainly concern four distinct developments: (a) the increase in (sea) refugee flows; (b) the closure of the so-called Balkan route in March 2016; (c) the EU-Turkey Statement of March 2016; ${ }^{4}$ and (d) the transposition into Greek law of EU Directive (2013/32/EU) on common procedures for granting and withdrawing international protection. Those developments resulted in new asylum legislation, in particular Law 4375/2016, adopted in April 2016 and amended in June 2016 (Law 4399/2016, Article 86). This law aimed to implement the aforementioned EU-Turkey Statement and the recast Asylum Procedures Directive (AIDA 2017; Greek Parliament 2016).

\footnotetext{
${ }^{4}$ The EU-Turkey Statement contains actions to address the refugee and migration crisis, including the return of all persons irregularly entering Greece after 20 March 2016 to Turkey.
} 
Through various provisions, the new asylum legislation reforms reception and asylum procedures, introduces a special regime applicable at border areas, regulates the backlog of cases (in particular those of the 'old regime'5), restructures the Appeals Committees and regulates matters relating to beneficiaries of international protection. A main aspect of the implementation of the new legislation is the different asylum procedures for those applicants who arrive in Greece after 20 March 2016 compared to those who were relocated to the mainland and had reached the country before this date (Koulocheris 2017; GCR 2016).

Developments in the legislative framework of asylum over the recent period, as reflected in particular in Law 4375/2016, in response to the EU-Turkey Statement, resulted in a clear division between reception and asylum procedures for those entering the country before and after 20 March 2016 and consequently for those staying on the mainland or on the islands. Thus, the Greek administration faced a double challenge (The Greek Ombudsman 2017): (a) to enable people who were transferring to and living in temporary accommodation facilities on mainland Greece to access the asylum process; and (b) to rapidly evaluate the asylum applications of those who crossed the sea borders after 20 March and were being held in the hotspots for readmission to Turkey.

The Administration addressed the first challenge in a quite satisfactory way since, by April 2017 over 27,000 1-year legal certificates for residence in the country had been granted through the pre-registration procedure. In contrast, the fasttrack border procedure has not operated adequately. One of the reasons for this was the limited number of national and EASO staff, which was not sufficient to tackle the number of applications they received (AIDA 2017; The Greek Ombudsman 2017). Another reason is the lack of coordination and insufficient distribution of competencies between public agencies, services, international organizations, NGOs and local authorities (Koulocheris 2017). Furthermore, the fast-track border procedure has predominantly taken the form of an admissibility procedure to examine whether applications may be dismissed (AIDA 2017), and asylum seekers have been practically excluded from relocation. Moreover, due to the priority of nationality for the submission and evaluation of the asylum applications, the asylum procedure has been severely delayed for non-prioritized nationalities. Consequently, the hotspots were overcrowded, reception conditions deteriorated in terms of sanitation and hygiene, and access to health care was limited, in particular for vulnerable groups (ECRE et al. 2016; NCHR 2017). There is no doubt that reducing the risk of the Reception and Identification Centres being transformed into permanent detention centers remains a major challenge.

\footnotetext{
${ }^{5}$ Asylum procedure governed by Presidential Decree 114/2010, applicable to claims lodged before 7 June 2013 (AIDA 2017).
} 


\subsection{The Legislative Framework on the Integration of Migrants, Asylum Seekers and Refugees into the Greek Labour Market}

\subsubsection{Migration and the Labour Market in the Context of the Economic Recession}

The Greek labor market has undergone a number of major changes in recent years due to the economic crisis and fiscal adjustment programs. The emergence of economic hardship and austerity policies led to rising unemployment and steadily falling GDP. In addition, the institutional protection framework for the labor market is not regulated. The main changes since 2010 are based on five key axes: first, the decline in the role of full employment and the expansion of flexible industrial relations, which favor sectoral rather than collective agreements between social partners. Secondly, the weakening of collective agreements and the shrinkage of wages. Thirdly, the spread of flexible working hours, fully adapted to the needs of markets. Fourth, the gradual liberalization of the institutional framework of redundancies. Fifth, the convergence of working conditions in the public and private sectors, leading to significant cuts in the employment protection of civil servants (Kouzis 2016).

At the same time, issuing residence permits has often been an obstacle to integrating migrants into the labor market. Greek migration policy and the subsequent access of migrants to the labor market was for a long time connected to the issuing of two permits, a work permit and a residence permit, particularly since the work permit was a prerequisite for the residence permit required for the purposes of working (Kapsalis 2018b). In addition, migration law aimed mainly to regularize illegal migration rather than promoting legal migration for employment purposes. Practically, the only two options for legal migration (that are often interconnected), that of recall/metaklissis ${ }^{6}$ and seasonal work are almost exclusively connected to the agricultural sector and their effectiveness is questionable (Triandafyllidou 2014). The ineffective application of these schemes results from the fact that, given the flexibility of labor needs in those sectors where migrants are employed, employers frequently demand changes to the needs they have for a workforce. It also seems that no substantive procedures for a dialogue between the various actors involved in the planning process have been put in place.

The interconnection between the economic recession, subsequent changes in the labor market and those legislative initiatives that aim to offer illegal migrants the opportunity to gain a legal status have led to the following paradox: there is a trend towards the greater convergence of the labor relations of Greek workers with those of MRAs than in the past. However, this trend is not necessarily due to any improvement in the working conditions of foreign workers. On the contrary, it is the

\footnotetext{
${ }^{6} \mathrm{~A}$ procedure that enables a non-EU national to enter and reside in Greece in order to provide paid work to a specific employer, in a specific field of employment.
} 
shrinking of labor rights and deregulation of the labor market that have exacerbated the working conditions of Greek citizens. As a result, there is a kind of convergence of common labor law with migration law, in a downward spiral (Kapsalis 2018a). As Kapsalis (2018a) states, it is of particular interest that in Greece, before the economic crisis, a migrant labor law with residual labor protection features was established, while during the Great Recession a corresponding residual labor protection framework was applied to native workers. Therefore, the labor protection both for native workers and MRAs has become a race to the bottom.

\subsubsection{The National Legislation on Migrant Access to the Greek Labor Market}

Since the beginning of the 1990s and the transformation of Greece from a sending to a receiving migration country, migration laws have clearly connected the stay of immigrants to their employment status and financial resources. In reality, the basic requirements for the legal residence of immigrants in Greece were, and remained so to a lesser extent, structured around the existence of a job, the filing of a formal employment contract, the compulsory presentation of a minimum number of social security (insurance) stamps $^{7}$ per year and the obligation to have an annual minimum income.

As mentioned above, the method of metaklissis, first introduced by Law $1975 / 1991$, remains one of the main paths for legal immigration in Greece, despite the fact that its previous application in the main sectors in which migrants are employed (construction, catering, small factories and retail services) proved rather unrealistic (Triandafyllidou 2014). In this procedure, there is a pre-approval of the entry of a foreign worker for a specific employer and for a specific type of work. Individual employment contracts are then concluded, with state control being exerted at all stages of their implementation. In the last quarter of each second year, the maximum number of dependent jobs allocated to Non-EU nationals per region and occupation is determined by the regional authorities. The same decision may provide for an increase in the maximum number of positions by up to $10 \%$ in order to cover unforeseen and emergency needs.

Given the difficulties for an effective application of the metaklissis scheme, in particular during the period of the economic recession, national legislation aimed at reducing the risk of increasing irregularity among migrants by increasing the validity of residence permits and reducing financial and duration of employment requirements for their renewal. In this respect, one of the most significant innovations of the 2014 Code (Law 4251/2014) was the abolition of the obligation to produce a written employment contract as a condition for renewal of a residence permit for the

\footnotetext{
${ }^{7}$ The completion of a minimum number of insurance stamps, through minimum working days per year, is a prerequisite for the renewal of a residence permit for employment purposes.
} 
purposes of paid employment. Thus, the reduced number of insurance stamps, the fulfilment of tax obligations and the existence of a valid health booklet are now the main requirements for the renewal of the residence permit related to employment. It is worth noting that, with the adoption of a Joint Ministerial Decision (51738/2014), the number of stamps needed for the renewal of legal residence becomes equal to the number of stamps required for the renewal of health insurance (50 stamps). These developments entail moving from a framework of work-centric immigration legislation to a framework geared towards maintaining legal residence due to the long-standing social ties immigrants may have developed (Kapsalis 2018a). This shift was due to the high unemployment rates, which meant that immigrants were unable to complete the minimum number of stamps per year and consequently, large groups of immigrant populations who have lived in the country for years would return, after many years, once again to an illegal residence status.

It is also worth noting that the Code regulates the situation of migrant investors wishing to settle in Greece. Thus, Article 16 states that Non-EU nationals are permitted to enter and stay in Greece in order to make an investment that will have a positive impact on national growth and the economy. A prerequisite for allowing them to enter and reside in Greece is a motion from the Department of Intragroup Services and Direct Investments to the Ministry for Development and Competitiveness, which means that immigrants with a high financial standing (250,000 euros or more) have the opportunity to pursue professional activities in Greece as they are granted a 5-year residence permit.

In 2015 a new law sought improvements to issues related to the participation of migrants in the labor market. More than the amendments of the Code of Greek Citizenship and the Migration Code, the new Law (4332/2015) aimed at incorporating two EU directives into national legislation. Directive 2011/98/EU concerned the single application procedure for a single permit to stay and to work, already introduced by previous national legislation (Law 3386/2005), to be issued to Non-EU nationals, and a common set of rights for third-country workers legally residing in a Member State. It also incorporates Directive 2014/36/EU on the conditions of entry and residence of Non-EU nationals for seasonal work. The most relevant provisions of Law 4332/2015 are related to the equal treatment of migrant workers, holders of a single permit, and of seasonal workers with EU nationals. Thus (in Articles 21A and B), both categories of Non-EU workers are entitled to equal treatment with EU nationals as regards the terms of employment (including minimum working age, working conditions, working hours and leave and holidays), the right to strike and take industrial action, education and vocational training, as well as the recognition of diplomas, certificates and other professional qualifications.

In 2016 the Greek state issued the special Circular 27430/2016, which gives access to the labor market to those immigrants who find themselves in a situation between illegality and legality, known as 'para-legality' (Kapsalis 2018b). This intermediate category includes irregular immigrants whose order to leave the country was postponed for humanitarian reasons and so they were granted a special certificate to remain in the country for 6 months, without the right to access social integration programs, and which is renewable for 6 months. The status of 
'para-legality' offers limited access to the labor market in specific sectors (such as agriculture, animal husbandry and domestic work) and geographical destinations (mainly rural areas).

\subsubsection{National Legislation for the Participation of Asylum Seekers and Refugees in the Greek Labor Market}

Aside from migrants, national legislation aims to regularize access to the labor market for the beneficiaries of international protection and asylum seekers (along with holders of a residence permit for humanitarian reasons).

In particular, refugee legislation is based on the Geneva Convention (1951) and mainly on Articles 17, 18, 19 and 24, which refer to the social rights of recognized refugees to social security and employment. In Greek legislation those rights are currently extended to persons who have been granted residence on subsidiary protection grounds. A relevant special regulation for the access to the labor market of the two groups of beneficiaries of international protection is contained in Presidential Decree 141/2013. This Presidential Decree aims to incorporate Directive 2011/95/ EU into domestic law. Article 27 of the Presidential Decree (incorporating Article 26 of the Community Directive) provides that beneficiaries of international protection are permitted to engage in employed or self-employed activity, in accordance with the provisions of Presidential Decree 189/1998 (A 140). This means that the beneficiaries of international protection must hold a permit to work, in the case of a salaried activity, or prove the existence of the necessary capital in the case of an independent economic activity.

Although Presidential Decree 141/2013 does not contain anything new regarding the preconditions for the access of the beneficiaries of international protection to the labor market, it provides clear improvements for other relevant issues. In particular, articles 27-31 foresee that persons who have been recognized as refugees or beneficiaries of subsidiary protection can participate in employment-related adult education programs, vocational training, including training courses for upgrading skills, workplace practice and counselling by employment services with the same conditions applicable to Greek citizens. These articles also allow these groups to utilize the available procedures for the recognition of diplomas, certificates and other formal qualifications as well as be assessed according to the same conditions as Greek citizens as regards the social security system, working conditions and health care. Nonetheless, despite the institutionalization of access to these benefits, policies and services for delivering these provisions have not yet been developed as public policies but take more the form of specific activities undertaken by NGOs (see Sect. 9.3.4).

The access of beneficiaries of international protection to the labor market was further facilitated by Law 4375/2016. This Law, which governs the current legislation on access to employment, is an adaptation of Greek Legislation to the 
provisions of Directive 2013/32/EU. The most important change brought about by the law is the abolition of the requirement for the possession of a permit to work as a condition for participation in the labor market (Ministerial Circular 17131/313/12-04-2016). Thus, beneficiaries of international protection and their families have the right to employment under the same conditions as nationals. The only condition for their participation in the labor market is the possession of the required residence permits. The Law also contains similar provisions (Article 69) as those of Presidential Decree 141/2013 on the same work conditions and access to services for beneficiaries of international protection and EU nationals. In practical terms, the labor rights and obligations of beneficiaries of international protection are defined by the same legal regime as for Greek workers. This arrangement concerns both the individuals themselves and the members of their families (Marouda and Sarandi 2017).

As for asylum seekers, Law 4375/2016 also facilitates their access to the labor market. As mentioned, the law abolishes the requirement for the possession of a permit in order to work, a provision foreseen by Presidential Decree 189/1998. Thus, according to article 71, asylum seekers have access to salaried employment and to the provision of services or work if they are in possession of the 'international protection applicant card' or 'asylum seeker's card'. In practical terms, there is no time restriction from the moment that an application is submitted to when the applicant can access the labor market. A last important point is that, as regards free access to public health services and medical treatment for uninsured citizens and the vulnerable population (Joint Ministerial Decision 25132/4-4-2016), asylum seekers now have access to health services on the same terms as nationals.

Despite the formulation of an institutional framework that gives asylum seekers and beneficiaries of international protection access to the Greek labor market, the reality is that these people remain mostly in the camps, with only a minority living in housing structures (Niemann and Zaun 2017; The Greek Ombudsman 2017; Kourachanis 2018). Their integration into the Greek labor market is thus extremely difficult in practice. The development of mechanisms ${ }^{8}$ to diagnose labor market needs that are compatible with their professional skills and the formulation of coherent employment policies are key challenges for their integration into Greek society (Karandinos 2016; Koulocheris 2017). Applying such mechanisms to channel MRAs into the gaps found in the labor market may in the future be a viable solution for their integration into the labor market.

\footnotetext{
${ }^{8}$ The Labor Market Needs Diagnosis Mechanism was set up by the Ministry of Labor, Social Solidarity in 2016, following the Action Plan adopted by the European Commission in 2015. It offers an extensive business network of stakeholders and social partners as well as a dedicated Information System. The National Institute of Labor and Human Resources (EIHRD) is responsible for presenting results, coordinating the network and managing the Information System.
} 


\subsubsection{Further Involvement of NGOs in Issues Related to the Integration of Refugees and Asylum Seekers into the Labor Market}

The 2015 refugee crisis marked a kind of turning point in the role of Civil Society Organizations (CSOs) as service provider for refugees and asylum seekers in Greece (Bagavos et al. 2019). First, the institutional involvement of NGOs is foreseen by recent asylum legislation (Law 4375/2016). In particular, if a Regional Asylum Office, Reception and Identification Centre, Temporary Reception Structure or Temporary Accommodation Structure has problems in operating smoothly, the processing of some tasks can be entrusted for a set period of time to civil society actors that meet the appropriate standards of quality and safety and have received the necessary permission. Exceptions to this option include those tasks that involve the exercise of public authority, such as the issuance of administrative acts, the examination of applications for international protection, the conduct of interviews and providing applicants with travel or identity documents.

Second, CSOs and NGOs in particular have undertaken a large spectrum of activities related to humanitarian aid, human rights, human trafficking, legal and administrative assistance, advocacy work, accommodation and housing, dissemination and information, socio-economic integration and culture. In practice, CSOs especially are attempting to manage the governmental gap of a migration policy designed with the integration of MRAs in mind. In this context NGOs in particular have been overseeing a majority of services, such as the provision of language courses, skills development training, and employability programs which aim to help integrate refugees and asylum seekers into the labor market. The focus is mainly on job searching techniques and curriculum vitae improvements rather than actually finding job positions for the persons concerned.

Empirical findings based on the opinions of refugees and asylum seekers themselves (Bagavos et al. 2019) seem to indicate that although CSOs have made an extremely significant contribution to humanitarian aid, legal and administrative assistance, the protection of human rights and the dissemination of information, they did not appear to be as successful in meeting refugees' and asylum seekers needs' in terms of their integration into the labor market. This was for a variety of reasons, such as: there were no expected results from the services provided; the actions did not have a follow-up; fragmented funding meant that services were provided for a limited period of time; or because CSOs and NGOs in particular were being asked to fill the gap created by the inability of public actors, supported by the public administration, to provide a clear integration policy. It is also probably related to the fact that, in some cases, refugees and asylum seekers perceive CSOs and NGOs as employment services providers that therefore have expectations that ultimately are not met.

It is, however, worth noting that although NGOs are key actors in the provision of employability services, public authorities have recently attempted to take a much more active role in this area. The trend towards the greater involvement of public 
authorities in the socio-economic integration of MRAs is reflected in the skills recognition activities. In that respect, perhaps the most typical example is the European Qualifications Passport for Refugees, ${ }^{9}$ which assesses refugees' education level, work experience and language proficiency in the absence of full documentation, by using a tested methodology and a structured interview. This was started in 2017 as a pilot project under the responsibility of the Council of Europe and involves several national and international actors, in particular the Greek Ministry of Education, Research and Religious Affairs. At the same time, the initiative of the Athens Coordination Centre for Migrants and Refugee ${ }^{10}$ Issues, where someone can attend job counseling sessions as well as other services, such as Greek and English language courses, must be seen as a sign of the further involvement of the public authorities in the social integration of MRAs.

\subsubsection{Anti-discrimination Legislation and Legal Instruments to Fight Informal Employment and the Exploitation of Workers}

The fight against discrimination is another dimension that can facilitate MRAs' access to the labor market. This is foreseen in Law 4443/2016 (Article 14), which aims to promote the principle of equal treatment and anti-discrimination: (a) on grounds of race, color, national or ethnic origin and generations; (b) religious or other beliefs, disability or chronic illness, age, or social status, sexual orientation, gender identity or gender in the field of employment and work; and (c) on the exercise of workers' rights in the context of the free movement of labor.

Under the 2016 law, the principle of equal treatment concerns: (a) conditions of access to employment and in the area of employment in general; (b) access to all types and levels of vocational guidance, apprenticeship, vocational training, retraining and vocational retraining, including the acquisition of practical professional experience; (c) working and employment conditions, in particular with regard to remuneration, dismissal, health and safety at work and, in the event of unemployment, reintegration and rehabilitation, as well as re-employment; and (d) membership of and participation in a workers' or employers' trade union or in any professional organization.

Over the recent period, the Greek state was more actively involved in the fight against undeclared work, an issue of significant importance for the country's labor market (ILO 2016; The Greek Ombudsman 2016). Specifically, according to the unpublished report regarding the plan 'Artemis', the percentage of undeclared work

\footnotetext{
${ }^{9} \mathrm{https} / / /$ blog.refugee.info/european-qualifications-passport/

${ }^{10} \mathrm{https}: / /$ www.accmr.gr/en/
} 
decreased from $19.2 \%$ in 2014 to $9 \%$ in $2018 .{ }^{11}$ The introduction of the method of payment and the retention of insurance contributions on the basis of the ergossimo was introduced, as a measure against undeclared work, for the first time in Greek legislation with Law 3863/2010. This is a kind of a special pay cheque for workers doing non-fixed or casual work (a form of employment in which the worker is not entitled to the regular provision of work) with one or more employers. The ergossimo does not focus on businesses or individual employers, but on workers, in particular those in specific disciplines, occupations or jobs (such as domestic workers, construction workers and agricultural workers). Consequently, it is a means of combating undeclared work, in particular tax evasion, and it is as such that it has been classified in the Greek legal order. It mainly concerns providers of services to households, such as domestic workers, (Kapsalis 2015). Several modifying interventions for the measure regarding were made in the following years. These amendments are mainly related to procedures for extending the measure of ergossimo to other sectors of employment as well as the procedures for monitoring its implementation. It is also worth noting that Article 2 of Law 4225/2014 attempts to include ergossimo in the labor inspections carried out by IKA (Social Insurance Institute). A large proportion of recipients who were targeted by this measure were immigrants, both domestic and farm workers. This is a positive measure that can lead to a greater reduction of undeclared work.

Lastly, in 2012, the Greek state incorporated EU Directive 2009/52/EU with Law 4052/2012. This Directive imposes minimum standards for the sanctions and measures against employers who illegally employ third-country nationals. The aim is to combat illegal immigration by preventing the illegal employment of migrants without residence permits in the Member States of the European Union. In Greek law this is reflected in Article 79 of the relevant law, which explicitly mentions the ban on the employment of illegally resident third-country nationals and in Article 80 which details the obligations of employers. These provisions set the framework for the application of labor protection measures.

\subsection{Conclusion}

There can be no doubt that migration remains one of the most significant socioeconomic issues for Europe - and Greece in particular. After the transformation of Greece from a sending to a receiving country, which resulted in the entry of a large number of economic migrants, the recent refugee crisis has modified the features of the migrant population. At the same time, contextual factors and changes in the economic environment over time have had a significant impact on the framing and implementation of policies on the legal status of MRAs, i.e. the first step towards

\footnotetext{
${ }^{11}$ Indicatively see https://www.efsyn.gr/oikonomia/elliniki-oikonomia/183580_meiosi-tis-adilotisergasias-sto-894-2018
} 
their socio-economic integration into the host society. Indeed, the legal stay of migrants and the availability of reception facilities for refugees and asylum seekers have been two significant issues as regards implementation of the policy. In this respect, immigration policy has undoubtedly contributed to simplifying and better managing the procedures for residence permits by reducing the risks of irregularity for a significant number of migrants. This is in the context of the persistent economic recession. In reality, since 2014, there has been a shift in Greek immigration law, which now aims to reduce the employment requirements that immigrants must fulfil for their residence permits to be renewed. There is no doubt that removing those requirements, in the context of a significant increase in unemployment, has enabled their further integration into the labor market.

Nevertheless, despite the great efforts made, both policies and public administration fail to fully address the challenges presented for the effective reception of refugees, which is a determinant preliminary stage for their future integration into the labor market. Developments in the legislative framework have led to a clear division between reception and asylum procedures for those entering the country before and after 20 March 2016 - the cut-off date established by the EU-Turkey Statement and consequently for those staying on the mainland or on the islands. Although the government addressed the challenge of enabling people who were transferring to and living in temporary accommodation facilities on mainland Greece to access the asylum process in a fairly satisfactory way by accelerating the procedure for issuing decisions on claims for international protection, it failed to provide means to rapidly evaluate the asylum applications of those who crossed the sea borders after 20 March and were being held in the hotspots for readmission to Turkey. Consequently, the hotspots were overcrowded and reception conditions were poor in sanitation and hygiene, while access to health care was limited. In such a context, the hope for integration into the labor market sounds fanciful.

The economic downturn and subsequent austerity measures were and remain important barriers for the integration of MRAs into the labor market. High unemployment rates among the overall population make targeted job creation for MRAs even more daunting since priority is given mainly to the fight against overall unemployment. Additionally, because of the economic downturn and decreasing household incomes, migrants' reduced employment in sectors such as construction, retail, cleaning, private care and domestic services has resulted in a challenging and unfavorable environment for the participation of MRAs in the labor market. In reality, given that third-country nationals are mostly low-skilled workers who are employed in low-skilled jobs, they remain extremely vulnerable to unfavorable economic conditions. This environment is likely to be more gloomy for refugees and asylum seekers than for migrants who are in a better position to secure a long legal stay, given the existence of informal ethnic networks among them, their knowledge of the Greek language and familiarization with the State administration. In other words, the factors enabling their integration into the labor market. Consequently, it is likely that MRAs' integration into the labor market will be further connected to an ethnic dimension; for example, migrant groups such Albanians and Pakistanis entering Greece in the first period of its transformation from a sending to a receiving country, 
are more likely to be better integrated in the labor market than the recent refugee streams from Afghanistan and Syria.

In practice, the framing and implementation of policies fail to deal with the barriers in place, such as the inability to transfer skills and credentials to a European context, the precarious legal status, limited education and language skills and limited work experience that immigrants are most of the time confronted with when they seek stable jobs in the European receiving countries. Those barriers are even more significant in Greece which is characterized by the polarization and fragmentation of policies aiming to facilitate the access of MRAs into the labor market and the limited involvement of the Public Employment Services in the labor market integration of MRAs. Barriers are also related to the features of the Greek labor market itself. Third-country nationals, particularly those who have resided in Greece for only a short time, are mostly pushed into the underground economy and undeclared work, an issue relevant in the context of adverse economic conditions. Despite the intensification of labor inspections, there has been no sign of improvement up to now (2020), mainly because of the non-systematic application of those inspections as well as common views among many people, who very often consider undeclared employment as something legitimate. Thus, migrants are trapped in low wage and low-skilled occupations, very often in the informal sector with no labor rights, without social insurance and with limited opportunities for any improvement in their socio-economic status. Although sectors such as catering, tourism and agriculture, which have experienced continuous growth in recent years, offer increasing opportunities to migrants for entering the labor market, those sectors are characterized by flexibility, irregularity, discrimination and undeclared work.

In addition, given the persistent economic recession in Greece and the lack of job search assistance programmes, the integration of MRAs, in particular refugees and asylum seekers, is hindered by the fact that they most likely desire relocation to another European country and are unwilling to be fully integrated into the labor market of a country which is seen more as a transit than a settlement country. It is worth noting that, according to empirical findings on the aspirations of young Syrian refugees, $74 \%$ of them intended to remain in the UK, compared to just $12 \%$ and $39 \%$ in Greece and Lebanon respectively (Karyotis et al. 2018). In addition, three out of four young Syrians in Greece aimed to reach another European country whereas the same ambition was expressed only by $13 \%$ and less than $2 \%$ of those living in Lebanon and the UK respectively. There is no doubt that this aspect acts as an important barrier for access and integration into the labor market of the newlyarrived refugees and asylum seekers in Greece.

The limited role played by the public authorities as a provider of services such as language courses, employability services and skills development training must be seen as significant barriers for the integration of MRAs into the labor market. Although NGOs have significantly contributed in these areas, public authorities have still not implemented many monitoring and validation processes, such as validation of the level of language knowledge or validation of skills. In general, despite the recent trend for the further involvement of the public authorities in the integration of MRAs into the labor market, the current increase in refugee flows risks 
diverting the attention of public actors to issues relating to the reception rather than to the integration of MRAs.

It is evident that the integration of refugees and asylum seekers will be a significant issue in the years to come. The management of the increased refugee flows of the last 5 years is being performed within a more protected humanitarian framework, while the labor integration of asylum seekers and refugees is still governed by a residual framework. To date, targeted employment policies have still not been designed. The consequence of this situation for asylum seekers and refugees may be the resumption of the labor integration paths followed by immigrants in the 1990s and 2000s, when there were high rates of undeclared work and any form of unfavorable employment was accepted in order to survive.

\section{References}

AIDA (Asylum Information Database). (2017). Country Report: Greece-2016 update. http://www. asylumineurope.org/reports/country/greece

AIDA (Asylum Information Database). (2019). Country Report: Greece-2018 update. http://www. asylumineurope.org/reports/country/greece

AIRE (Advice on Individual Rights in Europe), ECRE (European Council on Refugees and Exiles). (2016). With Greece. Recommendations for refugee protection. Report on Greece. http://www. asylumineurope.org/sites/default/files/resources/with_greece.pdf

AmnestyInternational.(2017). Greece:Ablueprintfordespair.HumanrightsimpactoftheEU-Turkey deal. https://www.amnesty.org/download/Documents/EUR2556642017ENGLISH.PDF

Bagavos, C. (2015). Chapter 11: International migration: The transformation of Greece from sending to receiving country. In A. Tragaki, C. Bagavos, \& D. Ntounas (Eds.), On demography and population changes. e-book. https://repository.kallipos.gr/handle/11419/4670 (in Greek).

Bagavos, C., Xatzigiannakou, K., \& Kourachanis, N. (2019). Civil society barriers and enablers Report on Greece. Report prepared for the SIRIUS research. https://www.sirius-project.eu/

Cavounidis, J. (2015). The changing face of emigration: Harnessing the potential of the new Greek diaspora. Report prepared for the Migration Policy Institute. https://www.migrationpolicy.org/ research/changing-face-emigration-harnessing-potential-new-greek-diaspora

Council of Europe. (1950). Convention for the protection of human rights and fundamental freedoms as amended by protocols No. 11 and No. 14 (European Treaty Series - No. 5). https:// rm.coe.int/1680063765

ECRE (European Council on Refugees and Exiles). (2016). Successful completion of preregistration of asylum seekers in Greece - More needed to meet long term concerns. News. https://www.ecre.org/successful-completion-of-pre-registration-in-greece-more-needed-tomeet-long-term-concerns/

ECRE (European Council on Refugees and Exiles), GCR (Greek Council for Refugees), et al. (2016). The implementation of the hotspots in Italy and Greece - A study. https://www.ecre. org/wp-content/uploads/2016/12/HOTSPOTS-Report-5.12.2016.pdf

EL.STAT. (Hellenic Statistical Authority). (2019a). Estimations of emigrants by age group and sex. http://www.statistics.gr/el/statistics/-/publication/SPO15/-. Accessed 21 June 2019.

EL.STAT. (Hellenic Statistical Authority). (2019b). Population estimates by age group, sex and broad group of citizenship. http://www.statistics.gr/el/statistics/-/publication/SPO18/-. Accessed 21 June 2019.

EMN (European Migration Network). (2015). Annual policy report 2015 - Annual report 2015 on Asylum and migration - Part 2. https://ec.europa.eu/home-affairs/sites/homeaffairs/files/whatwe-do/networks/european_migration_network/reports/docs/annual-policy/annual-policy-12a_ greece_apr_part2_english.pdf 
European Commission. (2017). Seventh report on the Progress made in the implementation of the EU-Turkey. Report from the Commission to the European Parliament and the Council. Brussels, 6.9.2017, COM(2017) 470 final. https://ec.europa.eu/neighbourhood-enlargement/ sites/near/files/20170906_seventh_report_on_the_progress_in_the_implementation_of_the_ eu-turkey_statement_en.pdf

GCR (Greek Council for Refugees). (2016). Remarks by the Greek Council on Refugees on Law 4375/2016. http://www.gcr.gr/index.php/el/news/press-releases-announcements/item/551-oiparatiriseis-tou-esp-epi-tou-nomou-4375-2016. (in Greek).

Greek Parliament. (2014). Explanatory report on the draft law on Ratification of immigration and social integration code. http://www.parliament.gr/UserFiles/2f026f42-950c-4efcb950-340c4fb76a24/k-koinent-eis.pdf. (in Greek).

Greek Parliament. (2016). Explanatory report to Law 4375/2016. http://goo.gl/RGbrKD. (in Greek).

Hassiotis, I. K. (1993). Historical overview of the Greek diaspora. Thessaloniki: Vanias. (in Greek).

ILO (International Labour Organization). (2016). Diagnostic report on undeclared work in Greece. Geneva: International Labour Organization. http://www.ilo.org/wcmsp5/groups/ public/\%2D\%2D-ed_emp/documents/projectdocumentation/wcms_531548.pdf

Kapsalis, A. (2015). Undeclared work in Greece. Assessment of modern anti-fighting measures, stay of immigrants stay of immigrants. Athens: Labour Institute of GSEE (Greek General Confederation of Labour), Study No 43. https://www.inegsee.gr/wp-content/uploads/2015/06/ Meleti-43-INE.pdf. (in Greek).

Kapsalis, A. (2018a). Migrant workers in Greece. Industrial relations and migration policy in times of memorandums. Athens: Topos. (in Greek).

Kapsalis, A. (2018b). The development of Greek migration policy and the invention of "Paralegality" in labour relations of immigrants. Koinoniki Politiki/Social Policy, 9, 67-87.

Karandinos, D. (2016). Labour market integration of asylum seekers and refugees-Greece. Report submitted to the Directorate of Employment, Social Affairs and Inclusion of the European Commission. http://ec.europa.eu/social/search.jsp?pager.offset=20\&langId=en\&searchType $=\&$ mode $=$ advancedSubmit $\&$ order $=\&$ mainCat $=0 \&$ subCat $=0 \&$ year $=0 \&$ country $=0 \&$ city $=0 \& \mathrm{a}$ $\mathrm{dvSearchKey}=$ Labour\%20 market\%20integration\%20of\%20asylum\%20seekers\%20and $\% 20$ refugees

Karyotis, G., Colburn, B., Doyle, L., Hermannsson, K., Mulvey, G., \& Skleparis, D. (2018). Building a new life in Britain: The skills, experiences and aspirations of young Syrian refugees (Building Futures Policy Report No 1). Glasgow: Policy Scotland. http://www.RefugeePolitics. net and www.PolicyScotland.gla.ac.uk.

Koulocheris, S. (2017). Integration of refugees in Greece, Hungary and Italy. Annex 1: Country case study Greece. Report prepared for the European Parliament's Committee on Employment and Social Affairs. http://www.europarl.europa.eu/RegData/etudes/STUD/2017/614194/ IPOL_STU\%282017\%29614194\%28ANN01\%29_EN.pdf

Kourachanis, N. (2018). Asylum seekers, hotspot approach and anti-social policy responses in Greece (2015-2017). Journal of International Migration and Integration. https://doi. org/10.1007/s12134-018-0592-y.

Kouzis, I. (2016). Crisis and memorandums deconstruct the employment. Koinoniki Politiki/Social Policy, 6, 7-20. (in Greek).

Labrianidis, L., \& Pratsinakis, M. (2016). Greece's new emigration at times of crisis (GreeSE Paper no. 99). Hellenic Observatory on Greece and Southeast Europe, LSE. http://eprints.lse. ac.uk/66811/1/GreeSE-No.99.pdf

Lazaretou, S. (2016). Fleeing of human capital: Recent trends in migration of Greeks over the years of the crisis. Bank of Greece, Bulletin of Economics, 43, 33-58. (in Greek). http://www. bankofgreece.gr/BogEkdoseis/oikodelt201607.pdf.

Marouda, M. N., \& Sarandi, V. (2017). Refugee law. Interpretation, charts, patterns. Athens: Nomiki Vivliothiki. (in Greek). 
Ministry for Migration Policy. (2018). National Register of Greek and Foreign Non-Governmental Organizations (NGOs) dealing with international protection, migration and social integration issues. https://mko.ypes.gr/home_in_mitroo_report

Ministry of Interior and Administrative Reform, UNHCR and ESPO. (2016a). What is preregistration? Information Poster. http://asylo.gov.gr/wp-content/uploads/2016/06/W001-2What-is-Pre-Registration-Poster.pdf

Ministry of Interior and Administrative Reform, UNHCR and ESPO. (2016b). End of large scale pre-registration on mainland Greece Joint Press Release. http://asylo.gov.gr/en/wp-content/ uploads/2016/08/EN-01.08.2016-Press-Release-end-pre-registration.pdf

Ministry of Migration Policy. (2018a). 2 Years since the Common Statement between European Union and Turkey, March 2016-March 2018. http://asylo.gov.gr/en/wp-content/ uploads/2018/03/EU-Turkey-Common-Statement-2-years_EN.pdf

Ministry of Migration Policy. (2018b). The work of the asylum service in 2017. Press Release 25.01.2018. http://asylo.gov.gr/en/wp-content/uploads/2018/01/Press-Release-25.1.2018.pdf

NCHR (National Commission for Human Rights). (2017). Annual report 2016. http://www.nchr. gr/images/ekthesi2016.pdf

Niemann, A., \& Zaun, N. (2017). EU refugee policies and politics in times of crisis: Theoretical and empirical perspectives. Journal of Common Market Studies, 56(1), 3-22.

Spirou, C. (2017). Exceptional reasons: Restoring legality and the notion of ties with the country. Problems in the correct application of Law 4251/2014 and Law 4332/2015. Paper presented at the 7th legal conference of Association of Trainees and New Lawyers "Modern Issues of Immigration Law: Immigration - Citizenship - Refugee", Patras, 10-12 November 2017. http://www.eanda.gr/sites/default/files/\%20\%CE\%A7\%CE\%A1\%CE\%97\%CE\%A3\%CE\%A 4\% CE\%9F\% CE\%A5\%20\%CE\%A3\%CE\%A0\%CE\%A5\%CE\%A1\%CE\%9F\%CE\%A5.pdf

Spyropoulou, A., \& Christopoulos, D. (2016). Refugees: "will we make it"? A management account and recommendations for a way out. Athens: Papazisi. (in Greek).

The Greek Ombudsman. (2013). Comments on the Draft Law on Ratification of immigration and social integration code. https://www.synigoros.gr/resources/paratiriseissxedionomou.pdf. (in Greek).

The Greek Ombudsman. (2015). Annual report. http://docplayer.gr/38967035-Synigoros-toypoliti-etisia-ekthesi.html. (in Greek).

The Greek Ombudsman. (2016). Combating discrimination-Special report. https://www.synigoros.gr/resources/docs/ee2016-14-diakriseis.pdf. (in Greek).

The Greek Ombudsman. (2017). Migration flows and refugee protection Administrative challenges and human rights issues. https://www.synigoros.gr/?i=human-rights.en.recentinterventions. 434107

Triandafyllidou, A. (2014). Migration in Greece: Recent developments in 2014. Report prepared for the OECD Network of International Migration Experts. http://www.eliamep.gr/wp-content/ uploads/2014/10/Migration-in-Greece-Recent-Developments-2014_2.pdf

Triandafyllidou, A. (2015). Migration in Greece: Recent developments in 2015. Report prepared for the OECD Network of International Migration Experts. http://www.eliamep.gr/wp-content/ uploads/2014/10/2015.pdf

Triandafyllidou, A., \& Gemi, E. (2018). Migration in Greece: Recent developments in 2018. Report prepared for the OECD Network of International Migration Experts. https://www.eliamep.gr/ wp-content/uploads/2017/11/Greece-report-for-OECD_Triandafyllidou-Gemi_Nov2018.pdf

UNHCR (United Nations High Commissioner for Refugees). (2019). Mediterranean situation Operational portal refugee situations. Accessed 21 June 2019.

Xypolytas, N. (2017). Preparation, allocation, habituation: The holistic approach to migrant exclusion. Social Cohesion and Development, 12(1), 57-71. 
Open Access This chapter is licensed under the terms of the Creative Commons Attribution 4.0 International License (http://creativecommons.org/licenses/by/4.0/), which permits use, sharing, adaptation, distribution and reproduction in any medium or format, as long as you give appropriate credit to the original author(s) and the source, provide a link to the Creative Commons license and indicate if changes were made.

The images or other third party material in this chapter are included in the chapter's Creative Commons license, unless indicated otherwise in a credit line to the material. If material is not included in the chapter's Creative Commons license and your intended use is not permitted by statutory regulation or exceeds the permitted use, you will need to obtain permission directly from the copyright holder. 